\title{
Institutional quality and catch performance of fishing nations
}

\author{
Ola Flaaten, \\ University of Troms $\varnothing$, BFE \\ Breivika, N-9037 Troms $\varnothing$ \\ Norway \\ ola.flaaten@uit.no \\ Office: +47 77645544 \\ Mobile: +4792460191
}

\begin{abstract}
The relationship between annual growth in the catches of fishing nations and the quality of the institutions of those nations is analyzed. Catch volumes are used as a proxy for development, since economic performance indicators based on a common set of definitions do not exist. 49 major fishing nations were selected for this study, including 22 OECD countries and several developing countries. Three general good governance indices, for government-efficiency (World Bank), corruption (Transparency International) and competitiveness (World Economic Forum) and one fishery specific FAO Code of Conduct compliance index were used. The correlation between fisheries' performance and the indices proved to be spurious, but OECD members achieved a statistically significant negative growth in catches between 1987 and 2007. The countries are divided into five groups, including 'Winners' and 'Losers', with reference to catch growth rates over two decades. Most of the OECD countries fell into the category 'Losers', whereas "Winners" includes many developing countries with lower quality institutions. Some countries had experienced an amazing growth in catches, while others had experienced a decline. The future prospects for both categories are discussed.
\end{abstract}

Keywords: Fisheries' performance; Resource curse; Developing countries; OECD countries; Sustainable development; Genuine saving.

\section{Highlights:}

- Annual growth in catches of fishing nations are compared with institutional quality

- Positive effects of good institutions known from the resource curse literature is not found

- OECD fishing countries have statistically significant negative growth in catches 19872007

- Several developing countries with low institutional quality are 'Winners' in growth in catches 


\section{Introduction}

Is richness in natural resources good for economic growth of a country or region? This question has been raised and discussed theoretically and empirically in several papers, and the sad answer has often been no [1],[2] and [3]. On the contrary, richness in natural resources often tends to be a 'curse' on economic growth, and not a 'blessing' as might be expected [4] and [5]. This paper discusses some related problems for a major renewable resource, fish from the ocean. Fish is a natural resource and as such it should in principle be included in empirical analyses of the resource curse literature. However, in the existing literature on this topic, emphasis has been placed largely on valuable mineral resources, such as oil and gas, since their share of export earnings in international trade is much higher. More recent developments in resource curse literature have demonstrated that countries with effective institutions perform better than the average in their management of natural resources, to the benefit of their economic growth and social welfare [6],[7],[8] and [5].

Fish have been caught in the wild by mankind for centuries, and the global catch has increased immensely over the last century, by a multiple of 35 [9]. The total world catch reached about 20 million tons in 1950 and continued to increase for some decades, but seemed to have peaked and levelled out in the 1980s and 1990s. The figure came to more than 80 million tons, excluding China, at the end of the 1980s, and more than 90 million tons, including China, at the second half of the 1990s [10] when the absolute peak came. Behind these figures, huge hidden differences between fisheries and countries have emerged over the years. In the resource curse literature, the main emphasis has been on how resource richness has affected economic growth. Since fish is a small natural resource for most countries, compared to larger and more valuable mineral resources, the approach in this paper is different from that of most of the resource curse literature. For some countries, fish may have been sufficiently important to affect the overall economic growth and development (in GDP or GDP per capita), at least for some periods in time, but probably not in terms of the global picture. For this reason, this paper investigates whether the performance of fisheries, as measured by the annual catch in each country, is affected by the quality of nation-wide institutions or fisheries institutions [11]. It would be preferable to have economic figures for the fishing nations of the world, but unfortunately such data is not collected by the Food and Agriculture Organization of the United Nations (FAO) or any other global international governmental institution in a comparable format. Instead we will rely on quantitative catch data from the FAO database [12], following the species selection from the FAO yearbook [10].

\section{Methods and data}

From a theoretical point of view, both increases and decreases in fish catches over time are possible. The former is the case mainly for previously biologically underexploited resources and the latter for overexploited resources, provided the fishing capacity or effort is sufficiently large. Fisheries development in general depends on both market and nonmarket forces, and on the nature of the management system in place. The main question is whether the fishing nations perform differently over time or if each of them is approaching a more or less stable level. As can be seen below, the former is usually the case, which raises several questions. The research questions and claims to be discussed are: firstly, is the performance of fisheries at its best in nations with generally effective institutions and little corruption? Secondly, are fisheries special, compared to other resource based industries, and does this industry need specialised institutions to perform well? Thirdly, is the performance of fisheries 
likely to be at its best in nations which have adopted and which comply with the UN-FAO Code of Conduct for Responsible Fisheries? Fourthly, is it true that the Code of Conduct Compliance (CCC) can be correlated with the good general governance indicators and that this in itself does not do much to explain fisheries compliance? Fifthly, is the performance of fisheries at its best in the developed nations, such as those in the Organisation for Economic Cooperation and Development (OECD), which have the economic means and knowledge needed for good governance? OECD is made up mainly of members from the most industrialised and developed countries of the world [13].

Governmental management and industry governance which is designed to reach policy objectives require the use of effective policy instruments. Such management in fisheries is usually based on one or more instruments among the main classes of technical regulations, input control and output control. Thus, the need for governmental interference and industry compliance with rules and regulations will be based on the existence of well-functioning governmental institutions, a business friendly environment and the absence of corruption that could jeopardize the functioning of the government - business relationship. An important question is whether fisheries can be considered special and so require special fisheries management institutions to perform well or if it is sufficient to have effective institutions in general in a country. A Nature article [14] reports on a comprehensive study of compliance with the FAO Code of Conduct for responsible fisheries (CCC) in major fishing nations. This is a survey of expert opinion and knowledge and does not comprise the actual performances of countries with respect to harvest quantity or value. The top six countries were, in declining order: Norway, USA, Canada, Australia, Iceland and Namibia. The six at the bottom were Egypt, Yemen, Nigeria, Angola, Myanmar, and at the very bottom North Korea. The Asian countries Indonesia, Thailand, Sri Lanka, Vietnam and Bangladesh belonged to the bottom fifteen of the 53 CCC-study countries [14]. Thus, the majority of those at the top of the list are industrialised and OECD member countries while most of those at the bottom are developing countries.

\subsection{Fishing nation data}

What constitutes a fishing nation? Several definitions of a fishing nation are used in the literature - [14] included those with the largest landings. FAO often uses the top 30 when displaying the big fishing nations [10]. In leaning to the FAO approach, this study initially selected 53 countries in the following way - a country should belong to at least one of the following 15 categories:

30 largest capture production countries (in tons) for: 1986-87, 1996-97 or 2006-2007

30 largest aquaculture countries (in tons) for: 1986-87, 1996-97 or 2006-07

30 largest aquaculture countries (in value) for: 1986-87, 1996-97 or 2006-07

30 largest capture + aquaculture production countries (in tons) for: 1986-87, 1996-97 or 200607

30 largest export countries in value for: 1986-87, 1996-97 or 2006-07.

Thus, the 53 countries chosen are not just those with the largest fish landings recently, but also some with large landings in the past, others which have a considerable aquaculture industry or are big in fish export value. Note that data for aquaculture value are available at the FAO, but data for capture fishing value is not. Value data is reported in local currencies and converted into USD by FAO and has in this paper been used only for the selection of the fishing nations. Data for 2007 was the most recently available from the FAO data base at the 
commencement of this project. To even out a little, the averages of two years have been used instead of data for single years. The national EEZs based on the Law of the Sea were established mainly in the second part of the 1970s and this created a change in fishing rights and power in favour of coastal states (for example Norway and Indonesia), at the expense of distant-water nations (including Japan and Russia). For this reason data from before 1986-87 has not been included. About ten years after the EEZs, the main transitional effects of this change may have vanished, but this still leaves a time series of 20 years of fishing.

In some cases made it was necessary to estimate figures for present day nations, including Russia and Ukraine, since in 1986-7 these two countries belonged to the Soviet Union, for which the FAO data are given ${ }^{1}$. In the analyses, four of the 53 countries were totally omitted. These were Uzbekistan and the Czech Republic, which are land locked countries (included in the 53 due to their aquaculture) and Belgium and Singapore, which are mainly fish trading countries and do not harvest much fish. Of the remaining 49 nations, Greenland and the Faroe Islands were omitted in the econometric analysis; since the internationally produced good governance indicators chosen for this analysis do not exist for these nations. Thus, 47 countries were to be included in the main econometric analysis. In the final analysis, however, Romania was omitted because an inspection of data showed that this country is a very clear outlier when it comes to catch development (see the last country in the Annex A data file).

\subsection{Fisheries development and good governance indicators}

For each of the two decades 1987-97 and 1997-2007 and for the whole period of 20 years the following indices (compounded annual percentage changes) were calculated (again, the terminal years of each period comprise an average of two years):

$i_{97}=$ annual change 1987 to 1997

$i_{07}=$ annual change 1997 to 2007

$i=$ annual change 1987 to 2007

The data set and the calculated compounded annual changes are given in the Annex A data file.

It is expected that modern fisheries management depends on good governance, both in the public and the private sector. As regards public institutions they are necessary to avoid the tragedy of biological and economic overfishing, as well as promoting resource rent and wealth creation (see index WGI below). For the private sector it is important to have a good business environment, promoting investment and fishing possibilities for fishermen and private firms (see index GCI below). In addition, in industries prone to continuous interactions between the public and the private sectors, minimal corruption with transparent and legally correct behaviour of all parties contributes to efficient use of resources and

\footnotetext{
${ }^{1}$ The estimates for Russia and Ukraine 1986-87 are calculated in the following way: The Soviet Union capture/aquaculture production from 1986 and -87 is multiplied by the Russian/Ukrainian fraction of the average of the former Soviet countries' total capture/aquaculture production in 1988 and -89, for which there are data. The former Soviet countries include: Armenia, Belarus, Georgia, Kyrgyzstan, Lithuania, Moldova, Republic of Turkmenistan, Uzbekistan, Azerbaijan, Estonia, Kazakhstan, Latvia, Tajikistan and Russian Federation.
} 
sustainable development (see index CPI below). Based on these arguments, the following three indicators were chosen to represent the institutions of good governance.

\section{WGI - The Worldwide Governance Indicators of the World Bank.}

This index reports aggregate and individual governance indicators for 213 economies over the period 1996-2009, using six dimensions of governance, including the two used in this study: government effectiveness and regulatory quality for 2007 [15] .

Governance consists of the traditions and institutions by which authority in a country is exercised. This includes the process by which governments are selected, monitored and replaced; the capacity of the government to effectively formulate and implement sound policies; and the respect of citizens and the state for the institutions that govern economic and social interactions among them [15].

\section{CPI - The Corruption Perceptions Index of Transparency International.}

This paper uses the average CPI score of the 2006 and 2007 indices [16]. The goal of the CPI is to provide data on the perceptions of corruption within countries. The CPI is a composite index, based on surveys of business people and assessments by local analysts. In each country it consists of sources that are considered credible, even though diverse sampling frames and somewhat different methodologies are used. These perceptions should enhance the understanding of real levels of corruption within specific countries. Overall, 14 sources are included in the CPI 2007 index which originate from 12 independent institutions. The common definition of corruption includes the misuse of public power for private benefit, for example the bribing of public officials, kickbacks in public procurement and embezzlement of public funds. Each of the country sources also assesses the extent of corruption among public officials and politicians in their country [16].

GCI - The Global Competitiveness Index of the World Economic Forum (WEF).

This paper uses the index in the Global Competitiveness Report 2006-2007 [17], to match the latest catch data available. For WEF the most important objective is to help policy makers and business leaders understand the key factors determining economic growth. By comparison of countries this helps explain why some countries are more successful than others in raising the incomes and opportunities of their populations. A key basis for the annual GCI reports is a worldwide executive opinion survey undertaken by a global network of more than 150 (as of 2012) partner institutions.

In addition to the general good governance indices WBI, CPI and GCI, the following specific fisheries index is used:

CCC - FAO (UN) Code of Conduct Compliance Index for Responsible Fisheries. This index, developed by and reported in $[11]^{2}$, is based on a thorough investigation of how some (53) major fishing countries have complied with the Code of Conduct for Responsible Fisheries (CC). The CC was developed in 1995 by the Food and Agriculture Organisation of the United Nations (FAO) and is a detailed consensus voluntary international instrument for the scientific and sustainable utilisation of fisheries resources. The CCC index is based on 44 questions to experts on fisheries management in their countries, and includes issues of management targets, compliance with the $\mathrm{CC}$, precaution, effectiveness, by-catch, discard,

\footnotetext{
${ }^{2}$ Also see http://www2.fisheries.com/archive/publications/reports/report14_2.php and http://www.nature.com/nature/journal/v457/n7230/full/457658a.html
} 
habitat impacts and IUU fishing, as well as the ability to maintain small-scale fisheries and coastal communities.

OECD dummy - The Organisation for Economic Cooperation and Development.

The member countries of this international governmental organisation are among the richest and most developed in the world. OECD functions as a think tank within many fields of economics and governance, including fisheries [18]. Its fisheries committee (COFI) has about 25 active member countries and all reports produced within this field of expertise are approved by consensus by COFI. During the years, including the two decades investigated in this paper, OECD has produced several reports guiding its member countries on fisheries governance issues, including fleet and catch management, trade and illegal, unreported and unregulated (IUU) fishing. OECD countries have the knowledge and means to manage their natural resources well. But have they succeeded with this for the fisheries? How are these countries performing compared to the non-OECD countries? To investigate such issues a dummy variable is included in the econometric analysis to distinguish between OECD member and non-member countries.

\subsection{Regressions}

The fishing industry is a small part of the economy in most countries, which makes the approach in this paper different from the resource curse literature which mainly uses GDP growth as the independent variable. In fact, in the resource curse literature fisheries and some other globally small resource industries are not included in the analysis emanating from the World Bank [5]. For catch performance, the possible correlations between annual average changes in the catches and the good governance indicators will be investigated.

Thus the task is to regress the dependent variable $i$ on the four independent variables WGI, CPI, GCI and CCC, as well as the dummy variable OECD. Ideally it would have been better to use a time series data set since the indicators may vary across time. However, such a complete data set for the four good governance indicators is not available, therefore the indices for the last one or two years of the investigated period are used.

(1) $i=B+\alpha_{1} W G I+\alpha_{2} C P I+\alpha_{3} G C I+\alpha_{4} C C C+\alpha_{5} O E C D$

The regression based on (1) has been carried out for the data set 'Capture production (Tons)' in the Annex A table.

\section{Results}

Descriptive statistics for the variables are shown in Annex B, Table B.1, based on data for 49 countries and entities. The average annual percentage change in the harvest of 1987-2007 for the 46 countries used in the regression is slightly negative ${ }^{3}$. This average is different from the average change in the total catch since it is not weighted with the size of the catches of specific countries.

\footnotetext{
${ }^{3}$ If Romania were included as the $47^{\text {th }}$ country the average annual change would decrease to -0.392 from -0.014 in Table A.1, excluding the Faeroe Islands and Greenland. However, including the latter two the average annual change over twenty years is $0.26 \%$, close to the average for the total harvest, $0.33 \%$.
} 


\subsection{Regression results}

The main regression results for the standardized coefficients are shown in equation (2) (tvalues in parenthesis), and more details are found in Table1.

\section{(2) $i=0.440(0.055)+0.061(0.122) W G I+0.095(0.179) C P I+0.010(0.024) G C I+0.011(0.035) C C C-0.477(-1.996) O E C D$}

The signs of the coefficients of the general good governance indicators WGI, CPI and GCI, as well as for the specific fisheries indicator CCC, are all positive, but far from being statistically significant (the $t$ values are given in parenthesis of equation (1)). For OECD the coefficient is negative and almost significant at 5\% level. There is a rather strong multicollinearity between the four good governance indicators, with correlation values between 0.806 and 0.935 , and the adjusted R-square is close to zero (Annex B Table B2). Further, Table 1 reveals high VIF values, which also proves strong multicollinearity, in particular for the three nation-wide good governance indicators WGI, CPI and GCI.

Table 1 Regression coefficients ${ }^{\mathrm{a}}$

\begin{tabular}{|c|c|c|c|c|c|c|c|c|c|}
\hline \multirow[b]{2}{*}{ Model } & \multicolumn{2}{|c|}{$\begin{array}{l}\text { Unstandardized } \\
\text { Coefficients }\end{array}$} & \multirow{2}{*}{$\begin{array}{c}\text { Standardized } \\
\text { Coefficients } \\
\text { Beta }\end{array}$} & \multirow[b]{2}{*}{$\mathrm{t}$} & \multirow[b]{2}{*}{ Sig. } & \multicolumn{2}{|c|}{$\begin{array}{c}95 \% \text { Confidence } \\
\text { Interval for B }\end{array}$} & \multicolumn{2}{|c|}{$\begin{array}{l}\text { Collinearity } \\
\text { Statistics }\end{array}$} \\
\hline & B & Std. Error & & & & $\begin{array}{l}\text { Lower } \\
\text { Bound }\end{array}$ & $\begin{array}{l}\text { Upper } \\
\text { Bound }\end{array}$ & Tolerance & VIF \\
\hline 1 (Constant) & .440 & 8.047 & & .055 & .957 & -15.823 & 16.703 & & \\
\hline OECD & -3.099 & 1.553 & -.477 & -1.996 & .053 & -6.237 & .038 & .382 & 2.621 \\
\hline WGI & .192 & 1.580 & .061 & .122 & .904 & -3.002 & 3.386 & .087 & 11.489 \\
\hline CPI & .118 & .660 & .095 & .179 & .859 & -1.217 & 1.453 & .078 & 12.861 \\
\hline GCI & .047 & 1.986 & .010 & .024 & .981 & -3.966 & 4.060 & .115 & 8.727 \\
\hline $\mathrm{CCC}$ & .027 & .776 & .011 & .035 & .972 & -1.541 & 1.596 & .220 & 4.545 \\
\hline
\end{tabular}

a. Dependent

variable: $i$

Source: own calculations

How to proceed when there is such a strong correlation between the independent variables? The simplest way is to use four simple OLS models; regress $i$ on each of the four variables WGI, CPI, GCI and CCC and calculate $R^{2}$. This has been done and one example of the resulted plots is given in Annex B Figure B.1. However, as one might have expected based on the analysis above, this approach does not give any clear-cut results. The second approach, and the one used in this paper, is a principal component analysis (PCA), computed with the help of SPSS. If the dependent variable $i$ should have depended mainly on one (or two or three) of the four independent variables, the good governance indicators, the PCA method usually would have been able to detect this dependency and its strength. The results for the case of two principal components are shown in Annex C. However, the only significant coefficient is the OECD dummy, which is negative, equal to -0.468 , and with $t=-2.118$ this coefficient is now significant at the 4\% level (Annex C Table C.4). Thus the OECD countries have generally had a negative development of fish catches in the period 1987-2007. The PCA 
(also with 3 and 4 principal components) did not reveal any hidden structure among the good governance indicators, but resulted in a statistical strengthening of the negative effect of the OECD dummy.

\subsection{Country ranking}

Based on the performance in two periods there are several ways of ranking countries, including merely to refer to the figures and a classification based on a selected set of criteria. The former is shown in Figure 1, with the three letter code for countries ${ }^{4}$, and the latter is described in Table 2. The categorisation in Table 2 of the countries' performance over the two decades from 1987 to 2007 is based purely on their catch performance and does not explain how the fish resources in the sea have developed.

Table 2. Categorisation of countries

\begin{tabular}{|l|l|l|l|}
\hline Category & $i_{97}$ & $i_{07}$ & $i$ \\
\hline Winners & + & + & + \\
\hline Consolidators & + & $0^{*}$ & + \\
\hline Revivers** & - & + & $+/-$ \\
\hline Risers and Decliners** & + & - & $+/-$ \\
\hline Losers & - & - & - \\
\hline
\end{tabular}

*Defined as $0.00+/-0.50$

** If $i$ is less than -0.50 the country has been categorised as a 'Loser'. This additional criteria moves Brazil, Germany and Canada from 'Revivers' to 'Losers', and Iceland, Chile, Greece and United Kingdom from 'Rise and Decline' to 'Losers'.

Along the horizontal and vertical axes of Figure 2 are the percentage average annual growth of fish harvest for 1987-1997 and 1997-2007 respectively. Since the concentration of countries is stronger when closest to the origin in Figure 1, this makes it difficult to distinguish between them. Figure 2 displays the same picture for some countries, but on a greater scale. In Figure 1 and Figure 2, straight border lines between the five categories have been drawn. To be a 'Winner' it is required that there is a positive growth in landings in each of the two decades, and of course over the whole period investigated. On the other hand, to be a 'Loser' requires that the corresponding changes are negative. For those in between 'Winners' and 'Losers', there is the question of whether there is decrease in the first decade and an increase in the second, or visa versa. The former are called 'Revivers' and the latter 'Rise and Decline'. Those with positive growth in the first decade and zero in the second are the 'Consolidators'. Since one decade of positive growth and one of negative growth may imply either positive or negative averages over the whole 20 year period, the countries with such growth patterns, and an annual average decrease of more than half a per cent, have been classified as 'Losers'. This moved three countries from 'Revivers' and four from 'Rise and Decline' to 'Losers' (Table 2 footnote).

\footnotetext{
${ }^{4}$ ISO 3-alpha shown in Annex A, taken from at http://www.unc.edu/ rowlett/units/codes/country.htm
} 


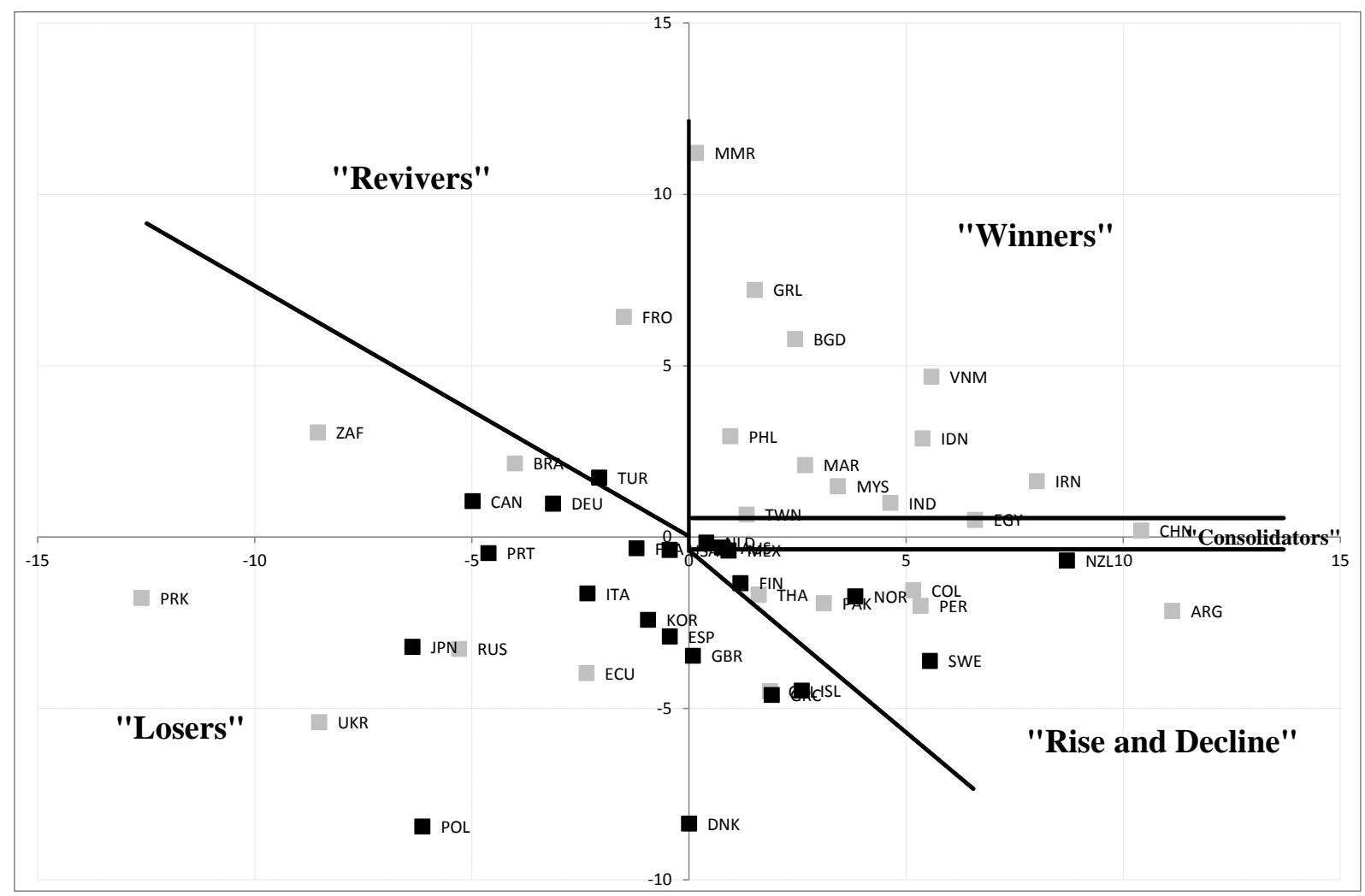

Figure 1. Catch performance of fisheries countries in two decades, with $i_{97}$ horizontally and $i_{07}$ vertically. Countries to the Northeast and the Southwest may be called 'Winners' and 'Losers', respectively. OECD countries in black. The three letter country codes are given in Annex A.

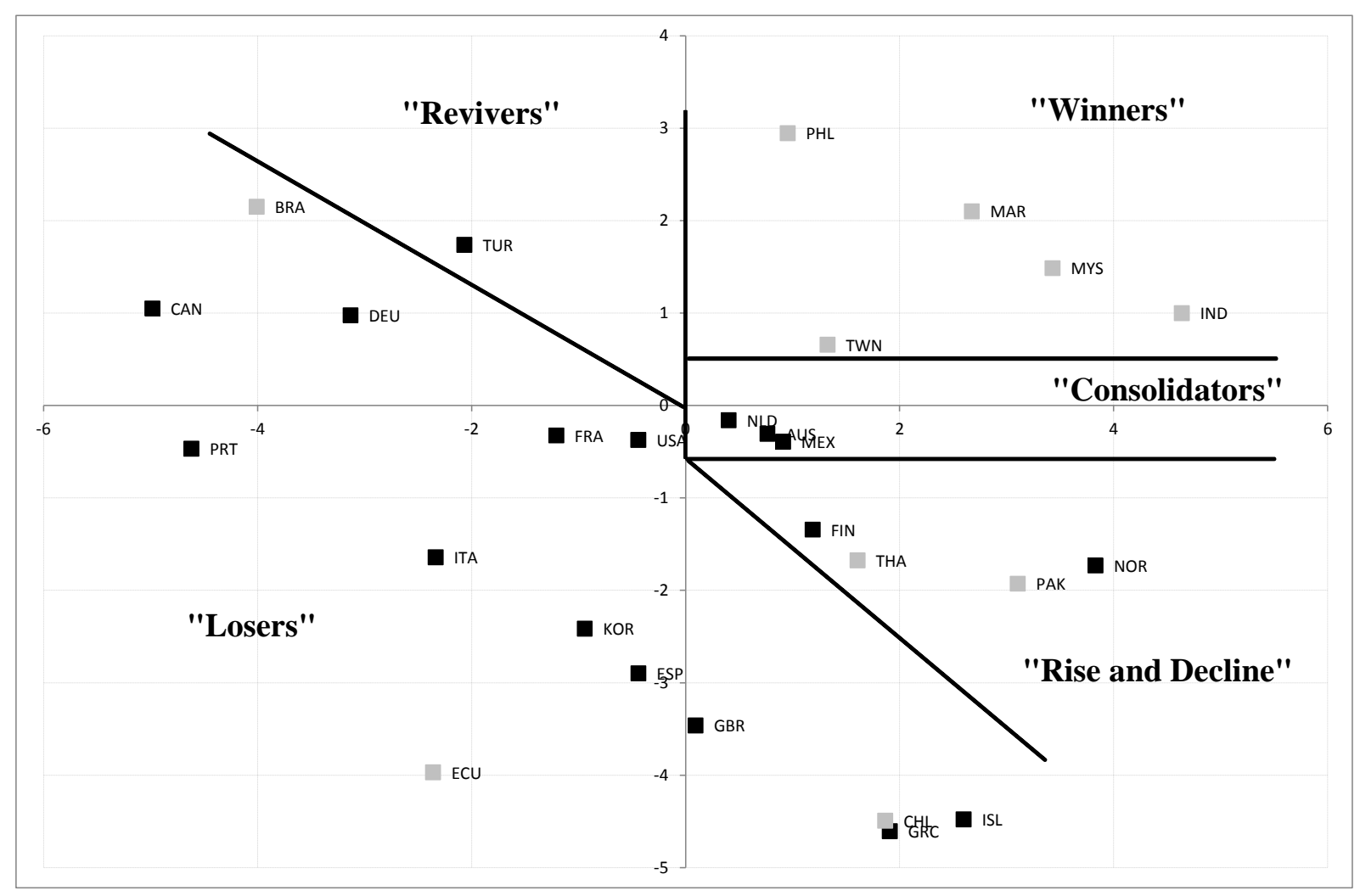


Figure 2. Catch performance of some of the fishing countries, corresponding to Figure 1, but with another scaling.

\section{Discussion}

This paper started out by exploring the connection between fish harvest growth and good governance institutions, partly as a supplement to the resource curse literature where fisheries, and some other resources, have been left out mainly due to data problems [5]. Even though this paper found weak positive correlations between fish harvest growth and good governance indicators, this is far from being statistically significant, be it the three general indicators or the specific fisheries Code of Conduct Compliance indicator. Thus it cannot be said that fisheries performance measured by the annual growth in catches is best in nations with generally good institutions and little corruption. To some extent it is rather the opposite. For example, among the countries with high harvest growth in the two decades ending in 1997 and 2007, i.e. to the North-east in Figures 1 and 2, are Indonesia, Myanmar, Vietnam, Bangladesh and Iran - and all these five are found towards the bottom of the corruption index CPI, as well as for the other two good governance indices, WGI and GCI (see Annex A). These countries also score among the lowest on the specific fisheries governance indicator CCC.

From the findings of this paper it seems that fisheries are special compared to other natural resource industries in the sense that growth in harvests is not statistically correlated to good governance indicators. As noted above, the resource curse literature usually studies the effects on GDP growth from, or correlation with, good governance institutions and the more traditional factors needed for economic production. In this paper, even though harvest growth is chosen as the dependent variable, it is likely that such positive growth contributes to the general economic growth of a country, particularly if the fishing industry is a major industry. However, in most countries nowadays the fishing industry is not of such importance, though there are exceptions. For example, in Vietnam the total export value of goods and services increased by a factor of about 13 from 1990 to 2007, and fish and fisheries products even more, increasing the industry share of total exports from about $9 \%$ in 1990 to about $12 \%$ in 2007, including aquaculture products [19]. With such a strong growth in fisheries production for export, it is likely that this contributed to the general economic growth (GDP) of about 7\% p.a. in this period, but to what extent remains to be seen.

Is fisheries performance best in nations which have adopted and comply with the UN-FAO Code of Conduct for Responsible Fisheries? Based on the Nature paper [14] one could answer this question affirmatively, since the CC Compliance of countries is shown to be positively correlated to general good governance indicators. Countries which perform well on the expert perception and knowledge based evaluation of how fishing nations have complied with the $\mathrm{CC}$ also do well on general good governance indicators. The same has been shown in this paper, though the good governance indicators are partly different from those in [14].

However, as demonstrated above, the real performance of fisheries, here defined as harvest development, may be very different from the experts' perception through the CCC index of how well fisheries are managed and developed. As noted above, the six top countries ranked in [14] are, in declining order, Norway, USA, Canada, Australia, Iceland and Namibia, but according to the ranking in this paper USA, Canada and Iceland are categorized as 'Losers', Norway as a 'Rise and Decline' country and Australia as a 'Consolidator'. They are all far from being 'Winners'. Namibia is not included among the 53 countries in this study since it did not meet any of the criteria used for the selection of fishing nations. One may regret this in 
hindsight since this smaller fishing nation has an interesting management history [20]. In the Nature paper quoted, the pass score for the Code compliance was $70 \%$, but not even the top ranking Norway at $60 \%$ meets this target. Of the ten countries at the lower end of the CCC ranking, which were included in this study, as many as six were 'Winners', namely Indonesia, Myanmar, Vietnam, Bangladesh, Iran, and Egypt. Only two out of the bottom ten are 'Losers', namely Ecuador and North-Korea - the latter being at the very bottom of the CCC list.

The Code of Conduct Compliance (CCC) is correlated with the general good governance indicators, both in this paper (see Annex B Table B.3) and in [14], though not as strongly as the WGI, CPI and GCI indices are to each other. Thus, in itself, the CCC does not add much to explain fisheries performance in the econometric sense; the general good governance indicators seem good enough for such a purpose - a result that may come as a surprise to fisheries' scientists and managers.

In the Introduction the question is raised as to whether fisheries' performance is best in the developed nations (such as the OECD) which have the economic means and knowledge needed for good governance. However, as demonstrated above, the actual results are far from good with respect to development in catches for this club of countries. On average, the 22 OECD countries included in this study experienced an annual decline of $1.9 \%$ in the years 1987-2007, whereas the 27 non-OECD had an average annual increase of $2.0 \%$ (Annex A). In 1958, the United Nations (UN) addressed the problems of open access to fisheries resources by allowing countries to establish 12 mile fishing zones, and from the mid 1970s there was a de facto recognition of the 200 miles Exclusive Economic Zone (EEZ). The latter was made possible through the UN's third Conference on the Law of the Sea (LOS), which lasted from 1973 to 1982 (UNCLOS III) when the LOS Convention was finally concluded. This development in international law made it possible for coastal states to improve their use of fisheries resources. Previously, many countries had invested in ocean going vessels; targeting fish stocks close to the 12 mile zone of other states; but from the mid-1970s, this came to an end in most parts of the world unless bilateral agreements had been made. From then until 1986-7, the first years of investigation in this study, countries had the ability to adjust their fish harvests to the available resources. If rich industrialised countries had overfished due to the previous international open-access characteristics of the fisheries, this could not be used as an excuse later. Actually it took some time for countries to reach agreements on how to manage trans-boundary resources. Whether this was more prevalent in OECD countries is not known, but if overfished initially they should have had positive growth in the following two decades instead of decline. Also, if they lost some of their harvests in the late 1970s, due to their expulsion from other countries' 200 miles EEZs, they had probably adjusted to this by 1986-7. On the other hand, in the coastal states that achieved more resources and control of these through their EEZs one might have expected that they increased catches for some years and then consolidated at a higher overall catch level than before. Thus more countries should have been found in the 'Consolidators' group than given in Figure 1.

The 'Winners' include many developing countries, but non from the OECD, and a pertinent question is if they won just because they had not yet achieved the technological and purchasing power to overexploit resources. If so, one might expect that later, one by one they would follow the richer countries in terms of overexploitation and that a fall in catches would be a result. This is a hypothesis about future development and may be tested after some years, but does not really contradict the results presented above. An alternative hypothesis for 
further investigation is that some countries reduced their catches to rebuild previously overfished stocks as a way of increasing their natural capital through genuine savings (see e.g. [9] [21] and [22]). The OECD has recently investigated and compared cases of rebuilding fisheries in an attempt to achieve an overview of some success stories [23] and to facilitate change in the member countries [24] and [25]. Denmark is an example of a rich, industrialised country with strong general institutions, but with weak actual fisheries performance during the second decade investigated (see DNK in Figure 2). Interestingly, a recent economic analysis of genuine savings in Denmark revealed that the fish wealth in real terms was halved from 1990 to 2009 [26]. It is tempting to quote Shakespeare "Something is rotten in the state of Denmark" [27], but luckily for the general welfare of the Danes fish amounts to less than $0.5 \%$ of the country's national genuine wealth.

This paper has used catch statistics from the FAO database where data has been provided by the member countries. With such statistics, one may ask how reliable they are. To the best of the author's knowledge there are no sources arguing for systematic flaws in the data that could significantly change the results of the econometric analysis of correlations between the harvest changes on the one hand and the governance indicators and the OECD dummy on the other. For the period(s) of investigation, the choice of initial and terminal years may of course have had an effect on the growth rates. As noted above the end year 2007 was chosen to include the most recent year for which FAO statistics were available at the commencement of this project, and a 20 year period was chosen to avoid coming to close back in time to the establishment of the new LOS regime that manifested itself during the late 1970s and early 1980s in 200 miles EEZs in most fishing nations.

\section{Conclusion}

In a way, the findings of this paper contrast the findings of the resource curse literature that good governance institutions create more economic growth. We say 'in a way' since the resource curse literature usually discusses resource abundance and the effects of good governance on economic growth and development, whereas this paper studies the correlation between good governance indicators and the growth in fish catches. It is demonstrated that fish capture performance over a twenty years period is (statistically) decoupled from the general good governance indicators developed by international governmental and nongovernmental organisations, as well as from the UN/FAO Code of Conduct for responsible fisheries performance indicators. This decoupling comes as a surprise, especially with regard to the effects on institutional quality of economic growth that have been shown in several studies [5].

Even more surprising is it that OECD countries perform on average significantly worse than the other countries in the period 1987-2007 with respect to catches. The average annual decline of the 22 OECD countries is almost $2 \%$, against an annual increase of $2 \%$ for the average of the 27 non-OECD countries (data in Annex A). The econometric correlation analysis, based on 46 countries, demonstrates a statistically significant negative effect on the annual growth in catches from the OECD dummy variable. This should warrant a closer scrutiny of the way rich countries manage their marine fish resources. When classifying the countries into five groups, including 'Winners' and 'Losers', as many as 12 of the 22 OECD countries are 'Losers', but none are among the 'Winners', and it will be a challenge for governments and stakeholders to change this. The OECD comprises mainly, but not only, rich developed countries; which should have the means and knowledge to improve. As noted above, the OECD fisheries committee has recently undertaken a study of the recovery of fish 
resources with the aim of learning from some success stories of members and to facilitate change.

Many developing countries are 'Winners' with respect to harvest growth during the twenty years being investigated, but they may simultaneously perform badly, according to the good governance indicators of the World Bank, the Transparency International and the World Economic Forum, as well if one follows the indicator developed by [14] for the UN/FAO Code of Conduct for Responsible Fisheries. Thus; despite badly functioning governments, corruption, unfriendly business climate and weak fisheries institutions in many developing countries, some of them have performed well with respect to the growth in fish catches. The big question is how long this may continue and what the changes will be. Fish in the wild is a renewable resource with natural limits to growth, and catches may in the long run be stabilised at about the maximum sustainable yield, or resources may be increasingly overfished with declining catches as a result. Several of the winner countries, including Indonesia and Vietnam, still have open-access fisheries and it is clear from both empirical evidence and theoretical analyses that sooner or later they will hit the limits to growth. After that a decline with respect to catches will come, unless they introduce thorough management systems. These might be economic or quantitative control with inputs, outputs or technical restrictions, including area and seasonal closures. This may of course be challenging, but to realise further economic surpluses from the fisheries will be even more challenging.

This article takes an important first step in investigating the performance of fishing nations around the world using simple but robust methods and data from a single source international governmental organisation, the FAO. Further investigations into why performances found in this article differ so much would be of interest, particularly between 'Winners' and 'Losers'. Is it mainly because of nature, such as natural stock fluctuations, ecosystem variation and climate change, or because of human activities, such as weak management systems, harvest cost and efficiency, and fish markets? Or is it a deliberate policy of some of the countries classified as 'Losers' to reduce harvests for a period of time to produce future benefits by increasing their genuine savings in fish resources? One other important topic for research is economic performance. If comparable sets of economic data, including landing values and harvest costs, become available, comparative studies using other indicators than harvest volume changes, such as landing value, profit, intra-marginal rent and resource rent would be useful. A first step in this direction could be to compare countries at a somewhat equal level with respect to economic development, e.g. OECD countries, or geographical location, e.g. EU member states. In fact much material, which could be used for such comparative studies, is already available in a range of different data bases. 


\section{ACKNOWLEDGEMENTS}

Research assistance from Sindre Myhr and Nguyen Ngoc Duy, as well as comments from Peder Andersen, Dale Squires and other participants at the Warming conference, University of Copenhagen, 1-3 September 2011, from Rintaro Yamaguchi and other participants at the $2^{\text {nd }}$ EAAERE conference, Bandung 2-4 February 2012, from, from Claire Armstrong, Øystein Myrland, Siv Reithe and other colleagues at the University of Troms $\varnothing$, is highly appreciated. 


\section{REFERENCES}

[1] Gelb A. Windfall Gains. Blessing or Curse? Oxford: Oxford University Press; 1988.

[2] Auty RM. Resource-based industrialization: sowing the oil in eight developing countries. New York: Oxford University Press; 1990.

[3] Gylfason T, Herbertsson TT and Zoega G. A mixed blessing: natural resources and economic growth. Macroeconomic Dynamics 1999; 3: 204-225.

[4] Sachs JS and Warner AM. The curse of natural resources. European Economic Review 2001; 45: 827-838.

[5] van der Ploeg F. Natural resources: Curse or blessing? Journal of Economic Literature 2011; 49(2): 366-420.

[6] Gylfason T. Nature, power and growth. Scottish Journal of Political Economy 2001; 48(5): 558-588.

[7] Mehlum H, Moene K and Torvik R. Institutions and the resource curse. The Economic Journal 2006; 116: 1-20.

[8] Mehlum H, Moene K and Torvik R. Mineral rents and social development in Norway. Working paper, Centre of Equality, Social Organization and Performance (ESOP), Department of Economics, University of Oslo; 2008.

[9] Arrow K, Dasgupta P, Goulder L, Daily G, Ehrlich P, Heal G, Levin S, Mäler KG, Schneider S, Starrett D, Walker B. Are We Consuming Too Much? The Journal of Economic Perspectives 2004; 18(3): 147-172.

[10] FAO - Food and Agriculture Organisation of the United Nations. The state of world fisheries and aquaculture 2010. Rome: ISBN-978-92-5-106675-1. Available at: http://www.fao.org/docrep/013/i1820e/i1820e00.htm. Accessed February 2012.

[11] Jentoft S. Institutions in fisheries: What they are, what they do, and how they change. Marine Policy 2004; 28(2): 137-149.

[12] FAO - Food and Agriculture Organisation of the United Nations. Rome: FishStat Plus Universal software for fishery statistical time series. Total Fishery, Capture and Aquaculture production 1950-2008. http://www.fao.org/fishery/statistics/software/fishstat/en. Accessed October 2010.

[13] OECD - Organisation for Economic Cooperation and Development. Paris: List of Members in 2006.

http://www.oecd.org/document/58/0,3343,en_2649_201185_1889402_1_1_1_1,00.html Accessed October 2011.

[14] Pitcher T, Kalikoski D, Pramod G, Short K. Not honouring the code. Nature 2009; 457(5): 658-9. 
[15] World Bank: The Worldwide Governance Indicator.

http://info.worldbank.org/governance/wgi/index.asp

http://papers.ssrn.com/sol3/papers.cfm?abstract_id=1682130\#\#. Accessed October 2010.

[16] Transparency International: Corruption Perceptions Index, 2006 and 2007,

http://www.transparency.org/policy_research/surveys_indices/cpi/2007

pp 4-7 (English version), and:

http://www.transparency.org/policy_research/surveys_indices/cpi/2007/methodology

"Complete version" accessed 19 November 2010.

[17] World Economic Forum: Global Competitiveness Report:

http://www.weforum.org/pdf/Global_Competitiveness_Reports/Reports/gcr_2006/gcr2006_su mmary.pdf, and:

http://www.weforum.org/pdf/Global_Competitiveness_Reports/Reports/gcr_2007/gcr2007_ra nkings.pdf, and:

http://gcr07.weforum.org/ (accessed 19 November 2010)

[18] OECD - Organisation for Economic Cooperation and Development. Paris: Review of Fisheries in OECD Countries 2009, Policies and Summary Statistics; 2010.

[19] Flaaten O. Fisheries development and management - Some reflections on Vietnam. In The Fourteenth Biennial Conference of the International Institute of Fisheries Economics \& Trade (IIFET), Nha Trang, Vietnam, July 22-25, 2008; The IIFET proceedings: Oregon State University; 2008.

[20] Wiium VH, Uulenga AS. Fishery management costs and rent extraction: The case of Namibia. In Schrank WE, Arnason R and Hannesson R (Eds.). The cost of fisheries management, Ch. 8. Hants: Ashgate; 2003.

[21] Asheim, G.B. and M.L. Weitzman. Does NNP growth indicate welfare improvement? Economics Letters 2001; 73(2): 233-239.

[22] Mota PM, Domingos T and Martins V. Analysis of genuine saving and potential green net national income: Portugal, 1990-2005. Ecological Economics 2010; 69: 1934-1942.

[23] Armstrong CW, Eide A, Flaaten O, Heen K. The Norwegian Northeast Arctic Cod Fishery, In: Economics of Rebuilding Fisheries. Case Studies of Fisheries Rebuilding Plans. Part 2: 202-219, Paris: OECD; 2011.

[24] Munro GR. Getting the economics and incentives right: Instrument choices in rebuilding fisheries; Working paper, University of British Columbia; 2010.

[25] OECD - Organisation for Economic Cooperation and Development. Paris: The Economics of Rebuilding Fisheries: Workshop Proceedings 2010 http://www.oecd.org/document/55/0,3746,en_2649_37401_45100919_1_1_1_37401,00.html Accessed March 2012.

[26] De Økonomiske Råd: Økonomi og Miljø 2012 (in Danish, Economy and Environment 2012, with English summary. Copenhagen. 2012. 
[27] Shakespeare W. Hamlet, the prince of Denmark, quoted from http://www.cheatsheetsonline.com/wp-content/uploads/2011/11/Hamlet-WilliamShakespeare2.pdf (c1600). (Downloaded 25th March, 2012). 
ANNEX A. Data file. Countries ranked according to production 2006-7

\begin{tabular}{|c|c|c|c|c|c|c|c|c|}
\hline \multirow[b]{2}{*}{ \# } & \multirow[b]{2}{*}{ Name } & \multirow{2}{*}{$\begin{array}{l}\text { Production } \\
\text { (Metric } \\
\text { Tons) } \\
2006-07\end{array}$} & \multirow{2}{*}{$\begin{array}{c}\text { Average } \\
\text { annual change } \\
\text { (\%), 1987-2007 } \\
i\end{array}$} & \multicolumn{5}{|c|}{ Indices } \\
\hline & & & & WGI & CPI & GCI & $\mathrm{CCC}$ & OECD \\
\hline 1 & China $(\mathrm{CHN})$ & 14645027 & 5.31 & 0.01 & 3.50 & 4.24 & 4.20 & 0 \\
\hline 2 & Peru (PER) & 7114018 & 1.67 & -0.08 & 3.50 & 3.94 & 3.80 & 0 \\
\hline 3 & $\begin{array}{l}\text { Indonesia (IDN) } \\
\text { United States of America }\end{array}$ & 4931854 & 4.13 & -0.26 & 2.30 & 4.26 & 2.70 & 0 \\
\hline 4 & (USA) & 4809940 & -0.41 & 1.50 & 7.20 & 5.61 & 5.80 & 1 \\
\hline 5 & Japan (JPN) & 4300835 & -4.79 & 1.26 & 7.50 & 5.60 & 5.40 & 1 \\
\hline 6 & Chile (CHL) & 3990022 & -1.31 & 1.41 & 7.00 & 4.85 & 4.60 & 0 \\
\hline 7 & $\begin{array}{l}\text { India (IND) } \\
\text { Russian Federation }\end{array}$ & 3852065 & 2.82 & -0.03 & 3.50 & 4.44 & 3.60 & 0 \\
\hline 8 & $(\mathrm{RUS})$ & 3369262 & -4.28 & -0.34 & 2.30 & 4.08 & 2.90 & 0 \\
\hline 9 & Thailand (THA) & 2501880 & -0.03 & 0.26 & 3.30 & 4.58 & 2.20 & 0 \\
\hline 10 & Philippines (PHL) & 2409356 & 1.95 & 0.03 & 2.50 & 4.00 & 3.30 & 0 \\
\hline 11 & Norway (NOR) & 2317627 & 1.05 & 1.65 & 8.70 & 5.42 & 6.00 & 1 \\
\hline 12 & Myanmar (MMR) & 2121185 & 5.68 & -1.91 & 1.40 & $3.66^{*}$ & 1.10 & 0 \\
\hline 13 & $\begin{array}{l}\text { Viet Nam (VNM) } \\
\text { Korea, Republic of }\end{array}$ & 1995500 & 5.13 & -0.30 & 2.60 & 3.89 & 2.00 & 0 \\
\hline 14 & $(\mathrm{KOR})$ & 1813674 & -1.68 & 1.07 & 5.10 & 5.13 & 4.50 & 1 \\
\hline 15 & Bangladesh (BGD) & 1465348 & 4.11 & -0.82 & 2.00 & 3.46 & 1.80 & 0 \\
\hline 16 & Mexico (MEX) & 1420558 & 0.26 & 0.31 & 3.50 & 4.18 & 4.00 & 1 \\
\hline 17 & Iceland (ISL) & 1363132 & -0.94 & 1.62 & 9.20 & 5.40 & 5.70 & 1 \\
\hline 18 & Malaysia (MYS) & 1336091 & 2.46 & 0.89 & 5.10 & 5.11 & 4.50 & 0 \\
\hline 19 & $\begin{array}{l}\text { Argentina (ARG) } \\
\text { Taiwan Province of }\end{array}$ & 1078695 & 4.49 & -0.46 & 2.90 & 4.01 & 3.20 & 0 \\
\hline 20 & China (TWN) & 1070927 & 0.99 & 0.96 & 5.70 & 5.41 & 3.50 & 0 \\
\hline 21 & Canada (CAN) & 1037466 & -1.97 & 1.64 & 8.70 & 5.37 & 5.80 & 1 \\
\hline 22 & Spain (ESP) & 890683 & -1.67 & 1.07 & 6.70 & 4.77 & 4.10 & 1 \\
\hline 23 & Morocco (MAR) & 878042 & 2.39 & -0.10 & 3.50 & 4.01 & 3.00 & 0 \\
\hline 24 & Brazil (BRA) & 781145 & -0.93 & -0.05 & 3.50 & 4.03 & 3.30 & 0 \\
\hline 25 & Denmark (DNK) & 760314 & -4.18 & 2.05 & 9.40 & 5.70 & 5.00 & 1 \\
\hline 26 & South Africa (ZAF) & 648687 & -2.75 & 0.58 & 5.10 & 4.36 & 5.50 & 0 \\
\hline 27 & United Kingdom (GBR) & 622036 & -1.68 & 1.71 & 8.40 & 5.54 & 4.50 & 1 \\
\hline 28 & Faroe Islands (FRO) & 602628 & 2.46 &.. &.. &.. & 5.00 & 0 \\
\hline 29 & Turkey (TUR) & 582749 & -0.16 & 0.30 & 4.10 & 4.14 & 1.90 & 1 \\
\hline 30 & France (FRA) & 544163 & -0.77 & 1.34 & 7.30 & 5.31 & 4.50 & 1 \\
\hline 31 & New Zealand (NZL) & 485532 & 4.01 & 1.69 & 9.40 & 5.15 & 5.50 & 1 \\
\hline 32 & $\begin{array}{l}\text { Pakistan (PAK) } \\
\text { Iran (Islamic Rep of) }\end{array}$ & 464805 & 0.59 & -0.51 & 2.40 & 3.66 & 3.00 & 0 \\
\hline 33 & $(\mathrm{IRN})$ & 424757 & 4.82 & -1.15 & 2.50 & $3.94^{*}$ & 2.50 & 0 \\
\hline 34 & Netherlands (NLD) & 424469 & 0.12 & 1.72 & 9.00 & 5.56 & 4.70 & 1 \\
\hline 35 & Ecuador (ECU) & 416860 & -3.16 & -1.06 & 2.10 & 3.67 & 2.90 & 0 \\
\hline 36 & Egypt (EGY) & 374193 & 3.54 & -0.35 & 2.90 & 4.07 & 1.70 & 0 \\
\hline 37 & Italy (ITA) & 301040 & -1.99 & 0.60 & 5.20 & 4.46 & 4.00 & 1 \\
\hline 38 & Germany (DEU) & 273301 & -1.08 & 1.58 & 7.80 & 5.58 & 4.40 & 1 \\
\hline 39 & Sweden (SWE) & 253752 & 0.97 & 1.76 & 9.30 & 5.74 & 4.40 & 1 \\
\hline
\end{tabular}




\begin{tabular}{|c|c|c|c|c|c|c|c|}
\hline 40 & Greenland (GRL) & 243357 & 4.36 & .. & .. & .. & .. \\
\hline 41 & Portugal (PRT) & 233726 & -2.54 & 0.99 & 6.50 & 4.60 & 4.50 \\
\hline 42 & $\begin{array}{l}\text { Ukraine (UKR) } \\
\text { Korea. Dem People's }\end{array}$ & 226121 & -6.96 & -0.52 & 2.70 & 3.89 & 2.10 \\
\hline 43 & $\operatorname{Rep}(\mathrm{PRK})$ & 205000 & -7.19 & -2.22 & $1.40^{*}$ & $3.46^{*}$ & 0.90 \\
\hline 44 & Australia (AUS) & 192592 & 0.23 & 1.73 & 8.60 & 5.29 & 5.80 \\
\hline 45 & Finland (FIN) & 157064 & -0.08 & 1.71 & 9.40 & 5.76 & $6.00^{*}$ \\
\hline 46 & Poland (POL) & 148650 & -7.29 & 0.59 & 4.20 & 4.30 & 3.60 \\
\hline 47 & Colombia (COL) & 119740 & 1.80 & 0.14 & 3.80 & 4.04 & $3.50^{*}$ \\
\hline 48 & Greece (GRC) & 97166 & -1.35 & 0.76 & 4.60 & 4.33 & $4.20^{*}$ \\
\hline 49 & Romania (ROU) & 6423 & -17.76 & 0.18 & 3.70 & 4.02 & $3.50^{*}$ \\
\hline & OECD countries & 23030463 & -1.89 & & & & \\
\hline & SUM 49 countries & 80303445 & 0.26 & & & & \\
\hline & SUM all & 89805508 & 0.33 & & & & \\
\hline & Fraction 49 of all & $89.42 \%$ & & & & & \\
\hline
\end{tabular}

.. Data lacking. *Inserted by interpolation, using the country ranking according to the other indices, minimum two. 
ANNEX B. Econometric results

Table B.1 Descriptive Statistics

\begin{tabular}{|l|r|r|r|}
\hline & \multicolumn{1}{|c|}{ Mean } & Std. Deviation & \multicolumn{1}{|c|}{$\mathrm{N}$} \\
\hline $\mathrm{i}$ & -.0144 & 3.28390 & 46 \\
OECD & .4783 & .50505 & 46 \\
WGI & .4953 & 1.03897 & 46 \\
CPI & 5.1587 & 2.63038 & 46 \\
GCI & 4.6087 & .72065 & 46 \\
CCC & 3.8522 & 1.33095 & 46 \\
\hline
\end{tabular}

Source: own calculations based on OECD, WGI, CPI, GCI and CCC data explained in the text.

Table B. 2 Model Summary ${ }^{\mathrm{b}}$

\begin{tabular}{|c|c|c|c|c|c|c|c|c|c|c|}
\hline \multirow[b]{2}{*}{ Model } & \multirow[b]{2}{*}{$\mathrm{R}$} & \multirow[b]{2}{*}{ R Square } & \multirow[b]{2}{*}{$\begin{array}{c}\text { Adjusted R } \\
\text { Square }\end{array}$} & \multirow{2}{*}{$\begin{array}{c}\text { Std. Error of } \\
\text { the } \\
\text { Estimate }\end{array}$} & \multicolumn{5}{|c|}{ Change Statistics } & \multirow[b]{2}{*}{ Durbin-Watso } \\
\hline & & & & & $\begin{array}{c}\text { R Square } \\
\text { Change }\end{array}$ & F Change & df1 & df2 & $\begin{array}{c}\text { Sig. F } \\
\text { Change }\end{array}$ & \\
\hline 1 & $.360^{\mathrm{a}}$ & .130 & .021 & 3.24933 & .130 & 1.193 & 5 & 40 & .330 & 1.4 \\
\hline
\end{tabular}
a. Predictors: (Constant), CCC, OECD, GCI, WGI, CPI
b. Dependent Variable: i

Table B.3 Correlations

\begin{tabular}{|ll|r|r|r|r|r|r|}
\hline & & $\mathrm{i}$ & OECD & WGI & CPI & \multicolumn{1}{c|}{ GCI } & \multicolumn{1}{c|}{ CCC } \\
\hline Pearson Correlation & $\mathrm{i}$ & 1.000 & -.343 & -.190 & -.199 & -.173 & -.153 \\
& OECD & -.343 & 1.000 & .752 & .775 & .705 & .643 \\
& WGI & -.190 & .752 & 1.000 & .935 & .917 & .873 \\
& $\mathrm{CPI}$ & -.199 & .775 & .935 & 1.000 & .930 & .855 \\
$\mathrm{GCl}$ & -.173 & .705 & .917 & .930 & 1.000 & .808 \\
$\mathrm{CCC}$ & -.153 & .643 & .873 & .855 & .808 & 1.000 \\
\hline
\end{tabular}

Source: own calculations.

Figure B.1 Partial regression plot 
Partial Regression Plot

Dependent Variable: i

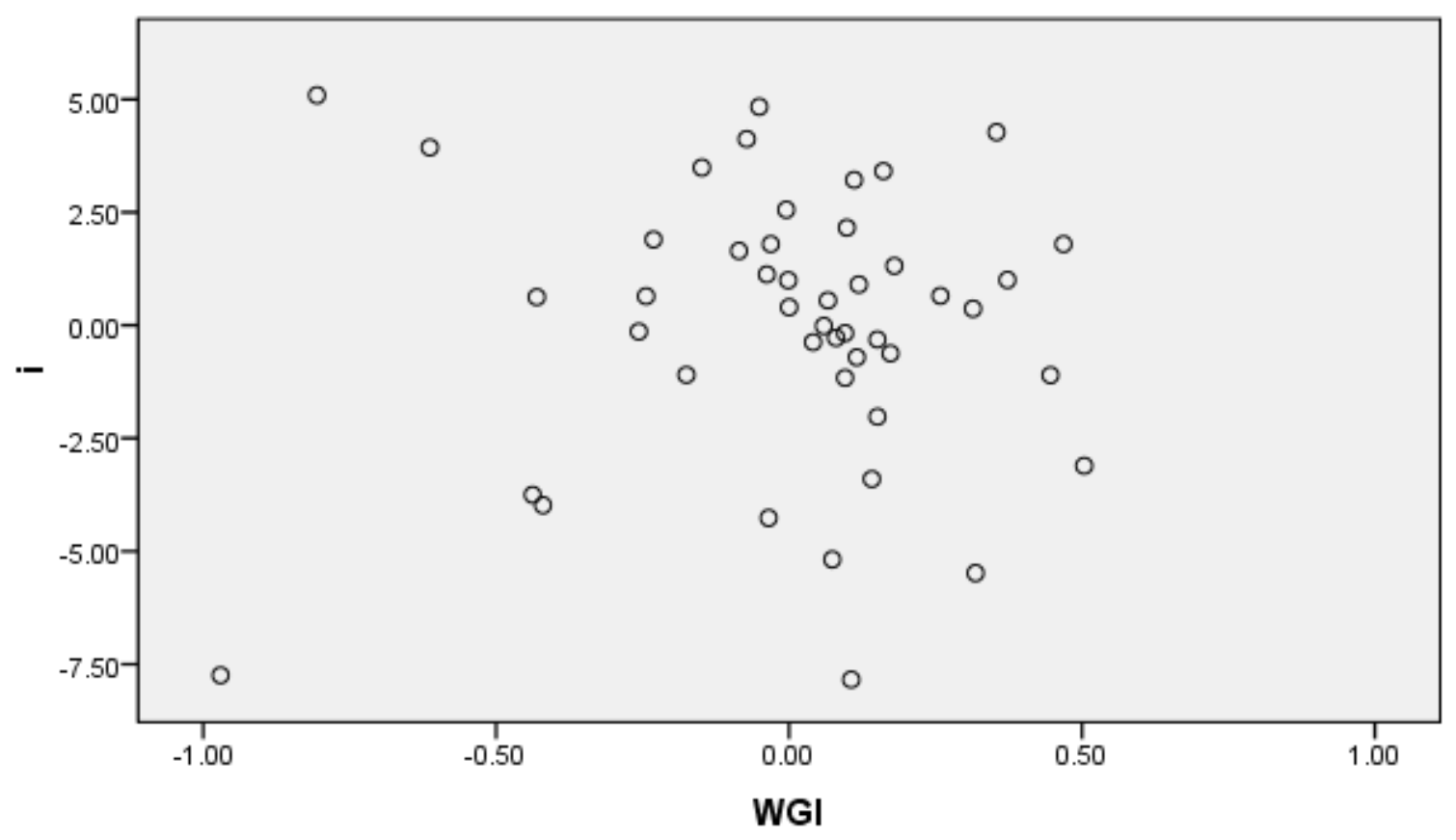


ANNEX C. Results of the Factor Analysis and its Regression ${ }^{5}$

Table C.1 Rotated Component Matrix ${ }^{\mathrm{a}}$

\begin{tabular}{|l|l|l|}
\hline \multirow{2}{*}{} & \multicolumn{2}{|l|}{ Component } \\
\cline { 2 - 3 } & 1 & 2 \\
\hline WGI & .777 & .589 \\
CPI & .820 & .533 \\
GCI & .886 & .426 \\
CCC & .478 & .876 \\
\hline
\end{tabular}

Extraction Method: Principal Component

Analysis.

Rotation Method: Varimax with Kaiser

Normalization.

a. Rotation converged in 3 iterations.

Table C.2 Variables Entered/Removed ${ }^{\mathrm{b}}$

\begin{tabular}{|l|l|l|l|}
\hline Model & Variables Entered & $\begin{array}{l}\text { Variables } \\
\text { Removed }\end{array}$ & Method \\
\hline 1 & $\begin{array}{l}\text { FAC2_1, FAC1_1, } \\
\text { OECD }\end{array}$ & & Enter \\
\hline
\end{tabular}

a. All requested variables entered.

b. Dependent Variable: $i$

Table C.3 Model Summary ${ }^{\mathrm{b}}$

\begin{tabular}{|c|c|c|c|c|c|c|c|c|c|c|}
\hline \multirow[b]{2}{*}{ Model } & \multirow[b]{2}{*}{$\mathrm{R}$} & \multirow[b]{2}{*}{$\begin{array}{c}\mathrm{R} \\
\text { Square }\end{array}$} & \multirow[b]{2}{*}{$\begin{array}{l}\text { Adjusted R } \\
\text { Square }\end{array}$} & \multirow[b]{2}{*}{$\begin{array}{c}\text { Std. Error of the } \\
\text { Estimate }\end{array}$} & \multicolumn{5}{|c|}{ Change Statistics } & \multirow[b]{2}{*}{$\begin{array}{l}\text { Durbin- } \\
\text { Watson }\end{array}$} \\
\hline & & & & & $\begin{array}{l}\text { R Square } \\
\text { Change }\end{array}$ & $\begin{array}{c}\mathrm{F} \\
\text { Change }\end{array}$ & df1 & df2 & $\begin{array}{l}\text { Sig. F } \\
\text { Change }\end{array}$ & \\
\hline 1 & $.360^{\mathrm{a}}$ & .129 & .067 & 3.17150 & .129 & 2.082 & 3 & 42 & .117 & 1.454 \\
\hline
\end{tabular}

a. Predictors: (Constant), FAC2_1, FAC1_1, OECD

b. Dependent

Variable: $i$

\footnotetext{
${ }^{5}$ The complete statistical output from the analysis is upon request available from the author.
} 
Table C. 4 Coefficients ${ }^{\mathrm{a}}$

\begin{tabular}{|c|c|c|c|c|c|c|c|c|c|}
\hline \multirow[b]{2}{*}{ Model } & \multicolumn{2}{|c|}{$\begin{array}{c}\text { Unstandardized } \\
\text { Coefficients }\end{array}$} & $\begin{array}{l}\text { Standardized } \\
\text { Coefficients }\end{array}$ & \multirow[b]{2}{*}{$\mathrm{t}$} & \multirow[b]{2}{*}{ Sig. } & \multicolumn{2}{|c|}{$\begin{array}{c}95 \% \text { Confidence } \\
\text { Interval for B }\end{array}$} & \multicolumn{2}{|c|}{$\begin{array}{l}\text { Collinearity } \\
\text { Statistics }\end{array}$} \\
\hline & B & Std. Error & Beta & & & $\begin{array}{l}\text { Lower } \\
\text { Bound }\end{array}$ & $\begin{array}{l}\text { Upper } \\
\text { Bound }\end{array}$ & Tolerance & VIF \\
\hline 1 (Constant) & 1.442 & .832 & & 1.734 & .090 & -.236 & 3.121 & & \\
\hline OECD & -3.046 & 1.438 & -.468 & -2.118 & .040 & -5.948 & -.143 & .424 & 2.360 \\
\hline FAC1_1 & .440 & .667 & .134 & .659 & .513 & -.907 & 1.787 & .502 & 1.993 \\
\hline FAC2_1 & .319 & .553 & .097 & .577 & .567 & -.797 & 1.435 & .731 & 1.368 \\
\hline
\end{tabular}

a. Dependent

Variable: $i$ 